\title{
RESEARCH
}

\section{An integrated Map of Human Chromosome 6p23}

\author{
Mark G. Olavesen, ${ }^{1,5}$ Angela F. Davies, ${ }^{1}$ S. John Broxholme, ${ }^{2}$ \\ Joanne L. Wixon, ${ }^{2}$ Gabrielle Senger, ${ }^{3,6}$ Dean Nizetic, ${ }^{4}$ \\ R. Duncan Campbell, ${ }^{2}$ and Jiannis Ragoussis ${ }^{1}$
}

${ }^{1}$ Division of Medical and Molecular Genetics, United Medical and Dental Schools of Guy's and St. Thomas's Hospital (UMDS), London SE1 9RT, UK; ${ }^{2} \mathrm{MRC}$ Immunochemistry Unit, Department of Biochemistry, Oxford OX1 3QU, UK; ${ }^{3}$ Cytogenetics Laboratory, Imperial Cancer Research Foundation, London WC2A 3PX, UK; ${ }^{4}$ Centre for Applied Molecular Biology, University of London, School of Pharmacy, London WC1N 1AX, UK

The human chromosomal band $6 \mathrm{p} 23$ is a Giemsa-negative (light) band that may be expected to be relatively gene rich. The genes for spinocerebellar ataxia type 1 (SCAl), guanosine monophosphate reductase (GMPR), DEK involved in a subtype of acute myeloid leukemia (AML), and the folate-sensitive fragile site FRA6A, have already been mapped to $6 \mathrm{p} 23$. Recent linkage data have suggested evidence for a susceptibility locus for schizophrenia in the region. We have constructed a single YAC contig of $\sim 100$ clones spanning the entire $6 \mathrm{p} 23$ band from $6 \mathrm{p} 22.3$ to $6 \mathrm{p} 24.1$ and covering 7.5-8.5 Mb of DNA. The YAC contig contains 55 markers including genetically mapped STSs, physically mapped STSs, anonymous STSs, anonymous ESTs, and ESTs from the genes mapped to the region. The order of the genetically mapped STSs is consistent with their order in the contig and some of the markers not resolved on the genetic map have been resolved by the YACs. Four of the YACs from $6 \mathrm{p} 23$ and covering $\sim 3 \mathrm{Mb}$ of DNA have been used to isolate -300 cosmids from a flow-sorted human chromosome 6 cosmid library, which have been organized into pockets. The proposed susceptibility locus for schizophrenia is most closely linked to D6S260, which is located within the YAC contig along with genetic markers $\leqslant 5 \mathrm{cM}$ on either side. Therefore, the presented materials are valuable reagents for characterization of the genomic region implicated in schizophrenia.

The short arm of chromosome 6 has evoked much interest because of the presence of the major histocompatibility complex (MHC) in the chromosomal band 6p21.3 (Spring et al. 1985; Senger et al. 1993), which contains $>110$ genes and gene fragments (Campbell and Trowsdale 1993), and the spinocerebellar ataxia type 1 (SCA1) locus in 6p23 (Orr et al. 1993). 6p23 is a Giemsa-negative (light) or R band, the "flavor" of which has been described as rich in Alu repeat sequences but not very rich in GC content (Holmquist 1992). In general, $\mathrm{R}$ bands have a high gene density, a high number of $\mathrm{CpG}$ islands, are early replicating, relatively $\mathrm{GC}$ rich and SINE rich (Craig and Bickmore 1993). Therefore, 6p23 may be expected to have a high gene density.

Several genes have already been assigned to

\footnotetext{
${ }^{5}$ Corresponding author. ${ }^{6}$ Present address: Institut für Humangenetik und Anthropologie, Kollegiengasse 10, D-07740 Jenå, Germany.

E-MAIL m.olavesen@umds.ac.uk; FAX 0171-955-4644.
}

this region of $6 \mathrm{p}$. The SCA1 CAG repeat locus has been assigned to 6p22-p23 (Orr et al. 1993) and 6p23.05-p24.2 (Volz et al. 1992). The DEK gene is involved in a $\mathrm{t}(6 ; 9)(\mathrm{p} 23 ; \mathrm{q} 34)$ balanced translocation responsible for a specific subtype of acute nonlymphocytic leukemia (von Lindern et al. 1992) and the guanosine monophosphate reductase (GMPR) gene has been assigned to $6 \mathrm{p} 23$ by fluorescence in situ hybridization (FISH) analysis (Murano et al. 1994). The FIM1 locus, the human homolog of the mouse proviral integration site for the Friend murine leukemia virus, Fim1, which is involved frequently in the early stages of myeloblastic leukemogenesis, has been mapped to $6 \mathrm{p} 23$ by in situ hybridization (Van Cong et al. 1989). The endothelin 1 (EDN1) locus and the transcription factor AP-2 (TFAP2) have also been mapped by in situ hybridization to $6 \mathrm{p} 23-\mathrm{p} 24$ (Arinami et al. 1991) and 6p22.3-pter (Gaynor et al. 1991b), respectively, and their locations refined to 6p24 (Davies et al. 1995), whereas the 
zinc finger DNA-binding protein (ZNF40/HIVEP1/MBP-1/PRDII-BF1) has been mapped to 6p22.3-p24 (Gaynor et al. 1991a). The renal sodium phosphate transport protein (NPT1/ SLC17A1) has been assigned to 6p21.3-p23 in a somatic cell hybrid panel (Chong et al. 1993). The rare folate-sensitive fragile site FRA6A has also been localized by cytogenetic techniques to $6 \mathrm{p} 23$ (Sutherland et al. 1983).

Genetic (Weissenbach et al. 1992; Gyapay et al. 1994) and physical (Orphanos et al. 1994) maps of human chromosome 6 and the process of mapping the SCA1 locus (Kwiatkowski et al. 1993) produced many anonymous microsatellite markers, a number of which were in the $6 \mathrm{p} 23$ region. Several anonymous expressed sequence tags (ESTs), previously mapped to chromosome 6 (Polymeropoulos et al. 1992), have been further sublocalized within chromosome 6 using a somatic cell hybrid panel, some of which are localized to 6p21.3-p23 (Pappas et al. 1995).

The central portion of $6 \mathrm{p}$ has been studied by several groups searching for linkage with cleft lip with or without cleft palate $(\mathrm{CL} / \mathrm{P})$ and cleft palate $(\mathrm{CP})$. Original data studying linkage to the blood clotting factor XIIIa (Eiberg et al. 1987) were not confirmed (Hecht et al. 1993; Vintiner et al. 1993), but more recently linkage has been shown to D6S89 in 6p23 (Carinci et al. 1995). However, detailed investigation of individuals with $\mathrm{CL} / \mathrm{P}$ associated with cytogenetic abnormalities provides evidence for a locus in $6 \mathrm{p} 24$ (Davies et al. 1995). D6S89 is $\sim 10 \mathrm{cM}$ from D6S470, the closest marker proximal of the balanced chromosomal breakpoints, and may be detecting linkage to the locus affected by the cytogenetic abnormalities.

Another linkage study has provided evidence for a susceptibility locus for schizophrenia on $6 p$ (Wang et al. 1995). Although their findings support a model for locus heterogeneity, their strongest linkage was obtained with the marker D6S260.

The critical region for the SCA1 gene in $6 \mathrm{p} 23$ was cloned in two yeast artificial chromosome (YAC) contigs, both spanning $\sim 2.5 \mathrm{Mb}$ from D6S274 to D6S443 (Banfi et al. 1993; Nemani et al. 1994). We have constructed a single YAC contig spanning from D6S422 at the distal end of $6 \mathrm{p} 22.3$ to connect with the YAC contig including TFAP2 and EDN1 at the proximal end of 6p24.1, thereby covering the entire $6 \mathrm{p} 23$ chromosomal band. The 7.5- to 8.5-Mb long contig includes 55 markers comprising genes, anonymous ESTs, and anonymous markers from all the available genetic and physical maps of the region allowing the integration of information from these different sources. The chromosomal localization of YACs across $6 \mathrm{p} 23$ has been verified by FISH analysis on metaphase chromosomes and the order of some markers not resolved in the YACs has been resolved by interphase FISH analysis. Toward a more detailed map of $6 \mathrm{p} 23$, we have also isolated -300 cosmids from a flow-sorted chromosome 6 cosmid library derived from $\sim 3 \mathrm{Mb}$ of the chromosomal band. These cosmids have been further sublocalized by the generation of a "cosmidpocket map" (Nizetic et al. 1994a) and the assignment of markers to cosmid clones.

\section{RESULTS}

\section{Construction of a YAC Contig Spanning the 6p23 Chromosomal Band}

The Centre d'Etudes du Polymorphisme Humain (CEPH) (Dausset et al. 1992), Imperial Cancer Research Foundation (ICRF) clones prefixed by AM (Larin et al. 1991) and Imperial Chemical Industries PLC (ICI) clones prefixed by RA (Anand et al. 1991) YAC libraries were screened with seven sequence tagged sites (STS) from the $6 \mathrm{p} 23$ region (Litt and Luty 1990; Weissenbach et al. 1992) (D6S89, D6S259, D6S260, D6S274, D6S285, D6S288, D6S289) and 47 clones were isolated. These were suplemented subsequently with 132 additional YACs identified from the first data release by Genethon (Cohen et al. 1993) using the Quickmap program to identify YACs mapping to $6 \mathrm{p} 22.3-\mathrm{p} 24.1$. The resulting sublibrary of 179 YACs was picked into two 96 well microtiter

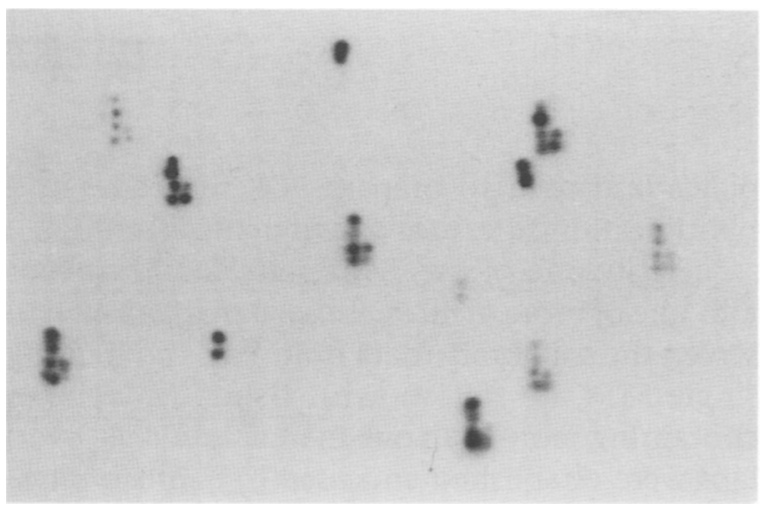

Figure 1 An example of the result of hybridization of an Alu-PCR probe $757 \mathrm{f} 7 / \mathrm{a} 8$ to a YAC sublibrary filter. The yeast colonies were spotted in different characteristic patterns from each 96-well microtiter plate to facilitate accurate scoring of positive clones. 
OLAVESEN EI AL.

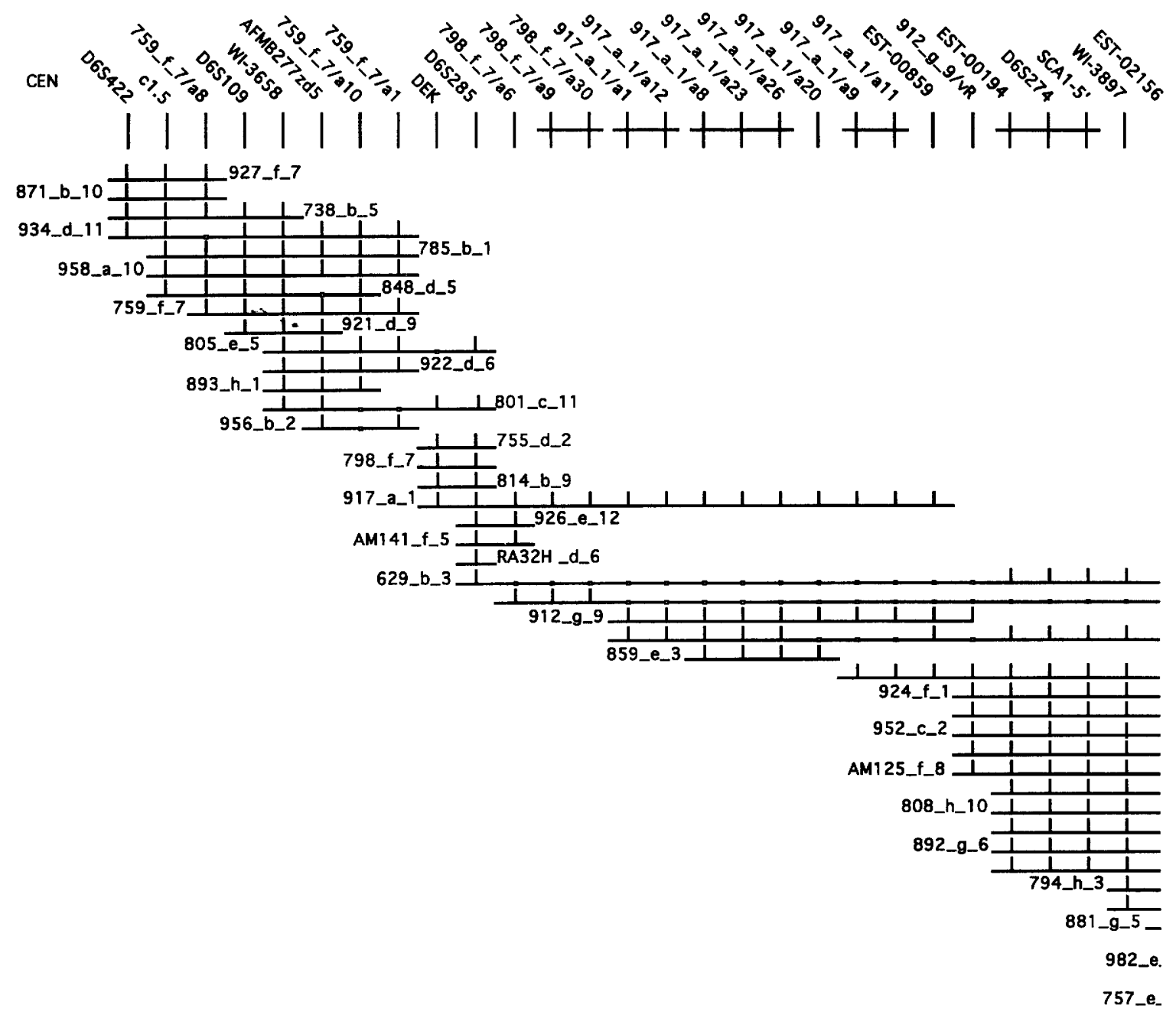

Figure 2 A schematic map of the YAC contig spanning $6 \mathrm{p} 23$ showing marker content of the clone inserts. The order of the markers was determined by colocalization to YAC clones and generating the minimum number of internal deletions within the YAC inserts. Horizontal lines show the regions spanned by the YAC inserts. Vertical lines show the positions of markers and their presence within YAC inserts. Small circles show the absence of markers in YACs, confirmed by repeated PCR screening, indicating the presence of internal deletions within YAC clones. Markers grouped together with short horizontal lines could not be resolved from each other in the YAC clones.

plates and used to prepare PCR templates and hybridization filters for subsequent screening.

Eighty-one of the YACs were found to contain one or more of 40 PCR-based markers used to screen the sublibrary (data from YACs containing single STSs are not shown). Using YAC clones containing more than one marker, multiple overlaps were established and used to confirm physical linkage between the markers and generate contigs. Expansion of the number of overlapping clones resulted in the construction of two contigs, the proximal contig covering the region from D6S422 in the distal part of $6 \mathrm{p} 22.3$ to
D6S285 and the more distal contig from EST00859/D6S1394E to the TFAP2 and EDN1 genes in the proximal part of 6p24.1 (Davies et al. 1995). A single gap was present between D6S285 and D6S274, which are separated by $2 \mathrm{cM}$ on the genetic map (Weissenbach et al. 1992; Gyapay et al. 1994). FISH analysis of interphase nuclei using 798 f 7 and 923 h_ 11 (which contain D6S285 and D6S274, respectively) revealed that the two YACs are separated by $450 \pm 61 \mathrm{~kb}$ (Fig. 3E below).

To generate additional markers centromeric of D6S274 YACs 759_f 7, 798_f 7 , and 917_a 1 were used as templates for inter-Alu PCR and the 

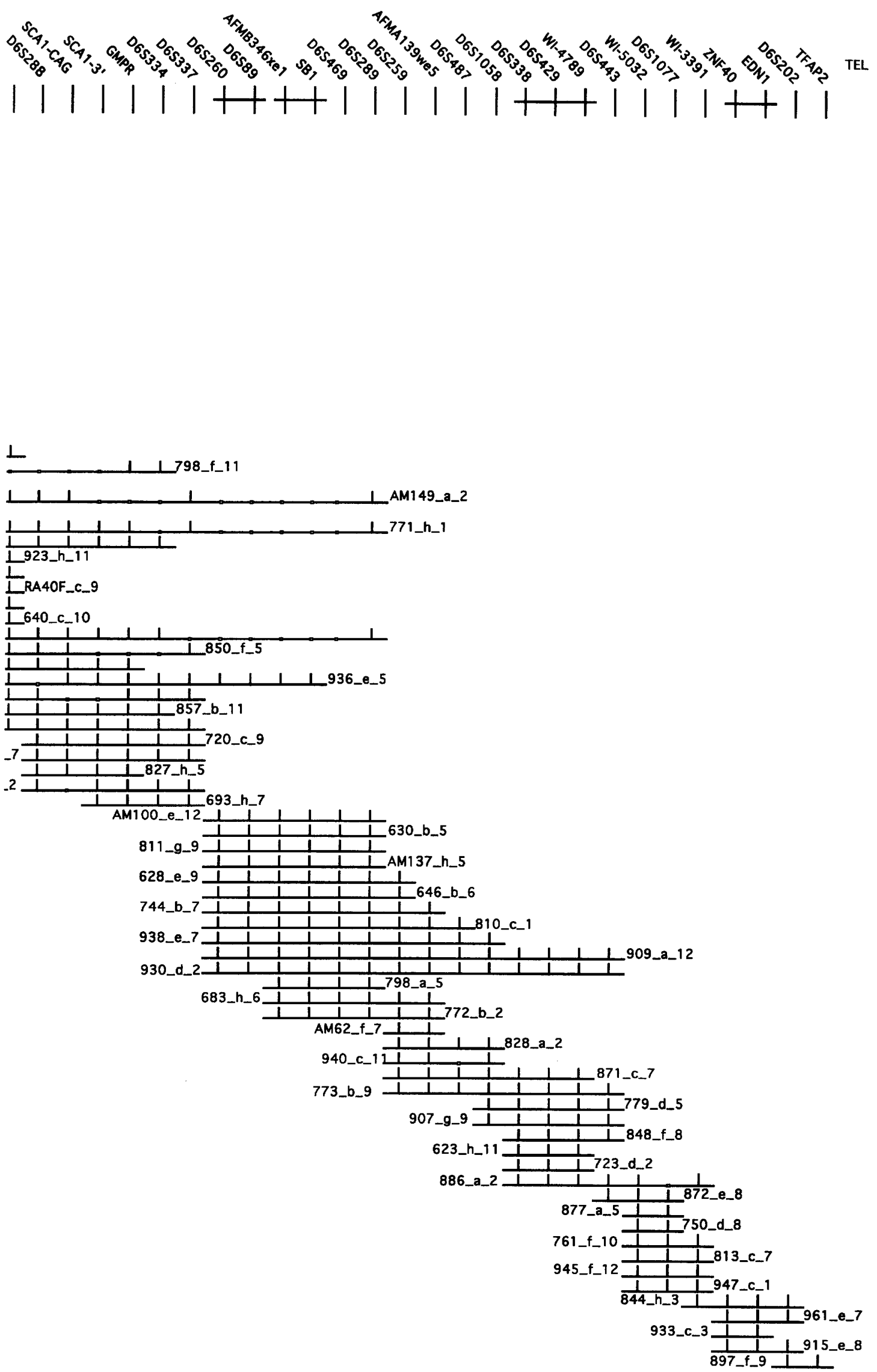

Figure 2 (continued) (See facing page for legend.) 
products were subcloned to isolate individual products. A number of these DNA fragments were then used as hybridization probes (denoted by the name of the YAC from which they were derived and the clone number) to increase the marker density between D6S422 and D6S285 and to "walk" between D6S285 and D6S274 (Fig. 1). The progress of gap closure was monitored by FISH analysis of pairs of YACs on interphase nuclei (Fig. 3E,F below). An additional probe was generated from YAC 912 . $g$. 9 by vectorette $P C R$ to confirm the overlap between this YAC and others containing D6S274.

The single YAC contig consists of 94 clones containing one or more markers from the $6 \mathrm{p} 23$ region; only the YACs containing two or more markers are included in Figure 2. All the markers are present in at least one YAC used for FISH analysis and mapped to $6 \mathrm{p} 22.3-\mathrm{p} 24.1$ on metaphase chromosomes (Table 1), thereby confirming their localization to this region. The entire set of markers are "doubly linked" to adjacent markers within the contig with four exceptions and all of these markers are present in additional YACs containing material derived exclusively from the 6 p23 region as determined by FISH analysis. The order of markers was established by the presence of two or more markers within a single YAC and by building up the number of overlapping clones. However, some YACs contain internal deletions and in some cases created ambiguities as to the marker order. The order presented in Figure 2 generated the minimum number of internal deletions irrespective of the number of markers missing in each case.

The order of genetic markers in the contig is consistent with the CEPH genetic map order of CEN-D6S422-D6S285-D6S274-D6S288-(D6S89, D6S260，D6S289，D6S469)-(D6S259，D6S429)D6S443-TEL (Gyapay et al. 1994) and others CEN-D6S109-D6S274-D6S288-(D6S89，D6S260, D6S289)-D6S259-EDN1-TEL (Jodice et al. 1993) and CEN-D6S109-AM10GA-D6S89-SB1-D6S202TEL (Kwiatkowski et al. 1993). The high number of markers compared with the number of YACs and internal deletions detected within 15 of the clones resulted in a number of markers that could not be resolved from one another or positions where the order may be ambiguous. Unresolved markers are: $798 \_$f $7 / \mathrm{a} 9$ and 798 f $7 / \mathrm{a} 30,917$ a $1 /$ a1 and 917a_1/a12, 917_a 1/a8 and 917_a $1 / 1 / a_{2} 3$ and 917_a_1/a26, 917_a_1/a9 and 917_a_1/a11, EST00194 and D6S274 and SCA1-5', D6S89 and D6S260, AFMB346xe1 and SB1, D6S338 and D6S429 and WI-4789, ZNF40 and EDN1. Pairs or sets of markers that could be exchanged are 917 a $1 / \mathrm{a} 9$ and 917 a $1 / \mathrm{a} 11$ and EST00859, D6S288, and SCA1-CAG, SCA1-3' and GMPR,

Table 1. Cytogenetic localization by FISH and STS content of YAC clones, ordered by STS content

\begin{tabular}{|c|c|c|c|}
\hline YAC & STS Markers in YAC & Chromosome 6 localisation & Other signals \\
\hline 844_h_3 & D6S202, EDN1, ZNF40, WI-3391 & $6 \mathrm{p} 24.1 / \mathrm{p} 23$ & \\
\hline $933 \_c \_3$ & EDN1, ZNF40 & $6 \mathrm{p} 24.1$ & \\
\hline 813_c_7 & WI-3391, D6S1077, WI-5032 & $6 \mathrm{p} 23$ & \\
\hline $761 \_$f_10 & WI-3391, D6S1077, WI-5032 & $6 \mathrm{p23}$ & \\
\hline $886 \_a \_2$ & WI-3391, WI-5032, D6S443, WI-4789, D6S429, D6S338 & $6 p 24.1 / p 23$ & \\
\hline 779 d_5 & D6S443, W1-4789, D6S429, D6S338, D6S1058 & $6 \mathrm{p} 24.1 / \mathrm{p} 23$ & \\
\hline AM62_I_7 & AFMA139we5, 06S259 & 6 p23 & \\
\hline \multirow[t]{2}{*}{$930 \_d \_2$} & D6S443, W1-4789, D6S429, D6S338, D6S1058, D6S487, AFMA139we5 - & $6 p 23$ & \\
\hline & - D6S259, D6S289, D6S469, SB1, AFMB346xe1, D6S89, D6S260 & & \\
\hline AM137_h_5 & D6S289, D6S469, SB1, AFMB346×01, D6S89, D6S260 & $6 \mathrm{p} 23$ & 8913 \\
\hline \multirow[t]{2}{*}{$892 \_9-6$} & GMPA, SCA1-3', SCA1-CAG, D6S288, EST02156, W1-3897, SCA1-5' - & $6 p 23$ & \\
\hline & - D6S274, EST00194 & & \\
\hline AM125_f_8 & EST02156, W1-3897, SCA1-5', D6S274, EST00194 & $6 \overline{623}$ & \\
\hline $923 \_h \_11$ & EST02156, W1-3897, SCA1-51, D6S274, EST00194 & proximal $6 \mathrm{p} 23$ & \\
\hline \multirow[t]{2}{*}{ AM149_a_2 } & D6S289, D6S337, SCA1-CAG, D6S288, EST02156, W|-3897, SCA1-5' - & $6 \mathrm{p} 23$ & \\
\hline & - D6S274, EST00194, EST00859 & & \\
\hline $912-9-9$ & EST00859 & $6 p 23$ & \\
\hline $928 \_\theta-5$ & EST00859 & 6 p22.3/p23 & $4 q 25,10 p 13$ \\
\hline $798+f=11$ & & $6 \mathrm{p} 23$ & \\
\hline $859 \_0$. 3 & & proximal $6 \mathrm{p} 23$ & $4 q 23$ \\
\hline $917 a_{n} 1$ & DEK, D6S285 & proximal $6 \mathrm{p} 23$ & \\
\hline $814 \_b_{-} 9$ & DEK, D6S285 & $6 \mathrm{p} 23$ & \\
\hline $798+7$ & DEK, D6S285 & distal $6 \mathrm{p} 22.3$ & 2p21, 3p13, proximal 4q22, 6q23 \\
\hline AM141_f_5 & D6S285 & 6p23 & \\
\hline RA32H_d_6 & D6S285 & proximal 6p23 & \\
\hline $759 \_f$ _7 & AFMB2772d5, WI-3658, D6S109 & 6 p23/p22.3 & \\
\hline $738_{-} b_{4} 5$ & WI-3658, D6S109, D6S422 & 6022.3 & 1944 \\
\hline
\end{tabular}


AFMB346xe1 and D6S289. The physical map of the SCA1 region (Orr et al. 1993) showed that D6S288 is proximal of the SCA1 (CAG) $)_{n}$ repeat and the mapping of cosmid clones containing SCA1-CAG, SCA1-3', and GMPR allowed us to position GMPR distal of the $3^{\prime}$ end of the SCA1 gene. Two hybridization markers for FIM1 (Van Cong et al. 1989) and solute carrier family 17 (sodium phosphate) member 1 (SLC17A1/NPT1) (Chong et al. 1993), mapped to 6p22.3-p23 and 6p21.3-p23, respectively, were not present within any of the YACs in the sublibrary and probably lie proximal to the contig.

An estimate of the size of the YAC contig can be made by summing the sizes of the smallest overlapping and nonoverlapping YACs with no known deletions across the contig. By these means the region covered is $7.5-8.5 \mathrm{Mb}$ and from the YACs mapped by FISH analysis of metaphase chromosomes, the $6 \mathrm{p} 23$ band is $6.5-7.5 \mathrm{Mb}$.

Some of the YACs exhibited instability during clonal growth as shown by variation in YAC sizes after demonstration of the presence of $6 \mathrm{p} 23$ markers in individual clones from the library plate wells (Table 2 ) in agreement with previous observations (Nemani et al. 1994) and with regrowth of some clones. In addition, mixtures of yeast clones taken from plate wells were used to prepare DNA to test for STS content to avoid the problems associated with clonal growth. Nevertheless, 15 YACs clearly exhibited internal deletions. All PCR markers apparently deleted from any YACs and any solitary markers, possibly caused by false-positive or false-negative results, were rechecked. In a model system (Kouprina et al. 1994) it has been shown that YACs exhibit a greater level of internal deletion during transformation (33\%) compared with the rate of deletion in mitotically growing yeast $(0.01 \%)$ and some of the YACs from the $6 \mathrm{p} 23$ region may have undergone deletion during construction of the YAC libraries. Our observations and those of others (Nemani et al. 1994) suggest that the mitotic instability of some of the YACs from $6 \mathrm{p} 23$ is $>0.01 \%$, but it is not known whether this is a feature of the sequences present in the YACs and the level of instability may vary from one region of the genome to another.

\section{Cytogenetic Analysis of YACs Derived From the 6p22.3-p24.1 Region}

The cytogenetic localization of 24 YACs was determined by FISH analysis of metaphase chromo- somes. All of the clones tested that lay within the YAC contig were assigned to the $6 \mathrm{p} 23$ region (Table 1 , Fig. $3 \mathrm{~A}-\mathrm{C})$. Five of the YACs $(21 \%)$ produced additional signals derived from other parts of the genome indicating chimerism in the YACs. One possible exception to this is the region of $4 \mathrm{q} 22-\mathrm{q} 25$, detected by YACs 928 e 5 , 859_e_3, and 798 f 7 , which may represent a region of homology between the $6 \mathrm{p} 22.3-\mathrm{p} 23$ boundary and this region of $4 \mathrm{q}$. However, careful examination of the images showed that the signals on $4 \mathrm{q}$ are clearly distinct from one another.

Two subsets of the YACs picked from the Genethon data mapping to 6p22.3-p24.1 were shown to contain markers EST00301/D6S315E (743 c 2,755 c 6,769 f 10,776 h 10 , and 808_h_5) and AFM268vh5 (759_f 4 and 977_g_2), but could not be incorporated into the contig. Representative YACs from each set were used for FISH analysis. YACs $759 \mathrm{f}_{4} 4$ and $977 \mathrm{~g} 22$ were localized to $6 \mathrm{q} 21$, whereas YACs $769 \mathrm{f} 10$ and 808 h 5 were localized to $6 \mathrm{p} 21.3$. The two YACs 769 f 10 and 808 h 5 are also present in the Genethon tile path data for $6 \mathrm{p} 21.3$ and are included within a YAC contig of the region (R.V.F. Mason and J. Ragoussis, unpubl.).

All of the PCR markers in the contig were present in at least one of the YACs used for FISH analysis and mapped to 6p22.3-p24.1. Careful examination of the results was used to position the signals within the chromosomal bands (see Table 1; Fig. 3A-C). Arrangement of the YACs in order according to their STS content with respect to the order of markers in the contig was used for comparison with the cytogenetic localizations (see Table 1). Examination of the cytogenetic localizations revealed that at the proximal end of 6p23 two YACs (928_e_5 and 798_f_7), localized to the $6 \mathrm{p} 22.3-\mathrm{p} 23$ boundary, overlap, on the distal side of, four YACs localized to $6 \mathrm{p} 23$. At the distal end two YACs, spanning $1.5 \mathrm{Mb}$, were localized to the $6 \mathrm{p} 23-\mathrm{p} 24.1$ boundary and overlap, on the proximal side of, two YACs localized to 6p23 (see Table 1). Therefore, it appears that there is no clearly defined linear cytogenetic boundary along the DNA; instead of the expected order of 6p22.3-p22.3/p23-p23-p23/p24.1-p24.1, the order observed for the assignments is $6 \mathrm{p} 22.3-(\mathrm{p} 23$ or $\mathrm{p} 22.3 / \mathrm{p} 23)-\mathrm{p} 23-(\mathrm{p} 24.1 / \mathrm{p} 23$ or $\mathrm{p} 23)-\mathrm{p} 24.1$. This apparently nonlinear relationship between cytogenetic localization and clone order along the chromosome may represent looping of the DNA in the chromatin structure that results in the observed discrepancies between cytogenetic 
Table 2. Sizes of YAC clones from the 6p22.3-p24.1 region in $\mathrm{kb}$

\begin{tabular}{|c|c|c|c|}
\hline YAC Name & YAC SIZES & YAC Name & YAC SIZES \\
\hline $927 \_7$ & $1020[1]$ & $982 \_\theta \_7$ & $1500[1]$ \\
\hline $871 \_b \_10$ & $1750[1]$ & $827 \_h \_5$ & $850[1]$ \\
\hline 738_b_5 & $800[2]$ & $757 \_0 \_2$ & $1250[1] 1790[1]$ \\
\hline 934_d_11 & $1500[1]$ & 693_h_7 & $780[1]$ \\
\hline $785 \_b \_1$ & $1670[1]$ & AM100_ $\theta_{-} 12$ & $640[2]$ \\
\hline $958 \_a \_10$ & $1690[1]$ & $630 \_b \_5$ & 900 [2] \\
\hline $848 \_d \_5$ & $800[1]$ & 811_g_9 & $1350[1]$ \\
\hline $759 \_7$ & $1420[1]$ & AM137_h_5 & $1050[2]$ \\
\hline 921 d_9 & $490[1]$ & 628_e_9 & $620[1,3]$ \\
\hline $805 \_0 \_5$ & 1400 [2] $1500[1]$ & 646_b_6 & 360 [3] $890[1]>1000[3]$ \\
\hline $922 \_d \_6$ & $1220[1] 1430[1]$ & 744_b_7 & 550 [2] 600 [2] 800 [2] 1320 [1] \\
\hline 893_h_1 & $1150[1]$ & 810_c_1 & 300 [2] $920[2]$ \\
\hline $801 \_c \_11$ & $1580[1]$ & $938 \_0 \_7$ & $300[3] 700[1,3] 1000[1,2] 1600[3]$ \\
\hline $956 \_b \_2$ & $1250[1]$ & $909 \_a \_12$ & 950 [2] 1000 [1] 1300 [2] 1600 [3] \\
\hline 755 d_2 & $1150[1]$ & $930 \_d \_2$ & $780[2] 1000[1] 1600[2,3]$ \\
\hline $798 \_f \_11$ & $450[1]$ & 798_a_5 & $1570[1]$ \\
\hline 814_b_9 & $1400[1]$ & $683 \_h \_6$ & 700 [2] 850 [2] \\
\hline $917 \_a \_1$ & $1350[1]$ & $772 \_b \_2$ & $350[2] 400[1,3] 520[2] 700[1,3] 900[1,3]$ \\
\hline $926 \_\theta=12$ & $1550[1]$ & AM62 $\& 7$ & $500[2]$ \\
\hline AM141_f_5 & $430[2]$ & 828_a_2 & $1100[2] 1200[2] 1300[1,3]$ \\
\hline RA32H_d_6 & $500[2]$ & $940 \_c_{-} 11$ & 450 [1] $1730[1] 1790[1]$ \\
\hline 629_b_3 & $210[1]$ & $871 \_c \_7$ & $1000[3] 1210[1]$ \\
\hline $798 \_7$ & 1200 [2] 1400 [2] $1540[1]$ & 773_b_9 & 650 [2] 760 [3] 800 [1] \\
\hline $912=9+9$ & $1340[1]$ & $779 \_d \_5$ & $880[1]$ \\
\hline AM149_a_2 & $1300[2]$ & $907 \_g \_9$ & $230[1] 600[1]$ \\
\hline $859 \_\theta+3$ & $1270[1]$ & $848 \_f-8$ & $870[1]$ \\
\hline $771 \_h \_1$ & 760 [2] 800 [3] 1400 [2] 1780 [1] & $623 \_h \_11$ & $>1000 \quad[3]$ \\
\hline $924 \_f \_1$ & $800[1,3] 1040[2] 1500[2]$ & 723_d_2 & $430[3] 450[1]$ \\
\hline $923 \_h \_11$ & $1000[1,2,3]$ & 886_a_2 & $150[1] 1600$ [3] \\
\hline $952 \_c \_2$ & $600[2]$ & 872_e_8 & $1220[1]$ \\
\hline RA40F_c_9 & $620[2]$ & $877 \_a \_5$ & $970[1]$ \\
\hline AM125_f_8 & 575 [2] & $750 \_d \_8$ & 1180 [1] 1770 [1] \\
\hline $640 \_c \_10$ & 700 [2] & $761 \_f \_10$ & $1510[1]$ \\
\hline $808 \_h \_10$ & $660[2] 880[1,3] 900[2]$ & $813 \_c \_7$ & $1750[1]$ \\
\hline $850 \div 5$ & 900 [1] 920 [2] 950 [3] & $945 \_f \_12$ & $1610[1]$ \\
\hline $892 \_9-6$ & $900[2]$ & $947 \_c_{-} 1$ & $470[1]$ \\
\hline $936 \_\theta-5$ & 650 [2] $1250[2] 1500[1,3] 1800$ & $844 \_h \_3$ & $1150[1]$ \\
\hline 794_h_3 & $890[1]$ & $761 \_0.7$ & $1340[1]$ \\
\hline $857 \_b \_11$ & $820[1]$ & $933 \_c-3$ & $1580[1]$ \\
\hline 881 g_5 & $760[1]$ & $915 \_\theta \_8$ & $1500[1]$ \\
\hline $720 \_c \_9$ & $1150[2]$ & 897_f_9 & $1750[1]$ \\
\hline
\end{tabular}

and clonal orders or may reflect the difficulty of accurate assignments at the lowest limits of resolution of metaphase mapping.

\section{Generation of a Cosmid Pocket Map Within 6p23}

To begin detailed molecular analysis of the $6 \mathrm{p} 23$ chromosomal band we have started to convert the $6 \mathrm{p} 23 \mathrm{YAC}$ contig into overlapping cosmids. This will facilitate detailed physical mapping and provide a primary resource for transcript mapping.

Total yeast DNA was isolated from YACs RA32H_d 6, AM149_a 2, 744_b_7, and 930_d_2 and used individually to probe high density cosmid filter grids of a flow-sorted human chromosome 6 cosmid library (Nizetic et al. 1991, 1994b). Three hundred and ninety-six cosmid clones were identified by one or more of the YAC clone probes, but not by total yeast DNA, and these were 

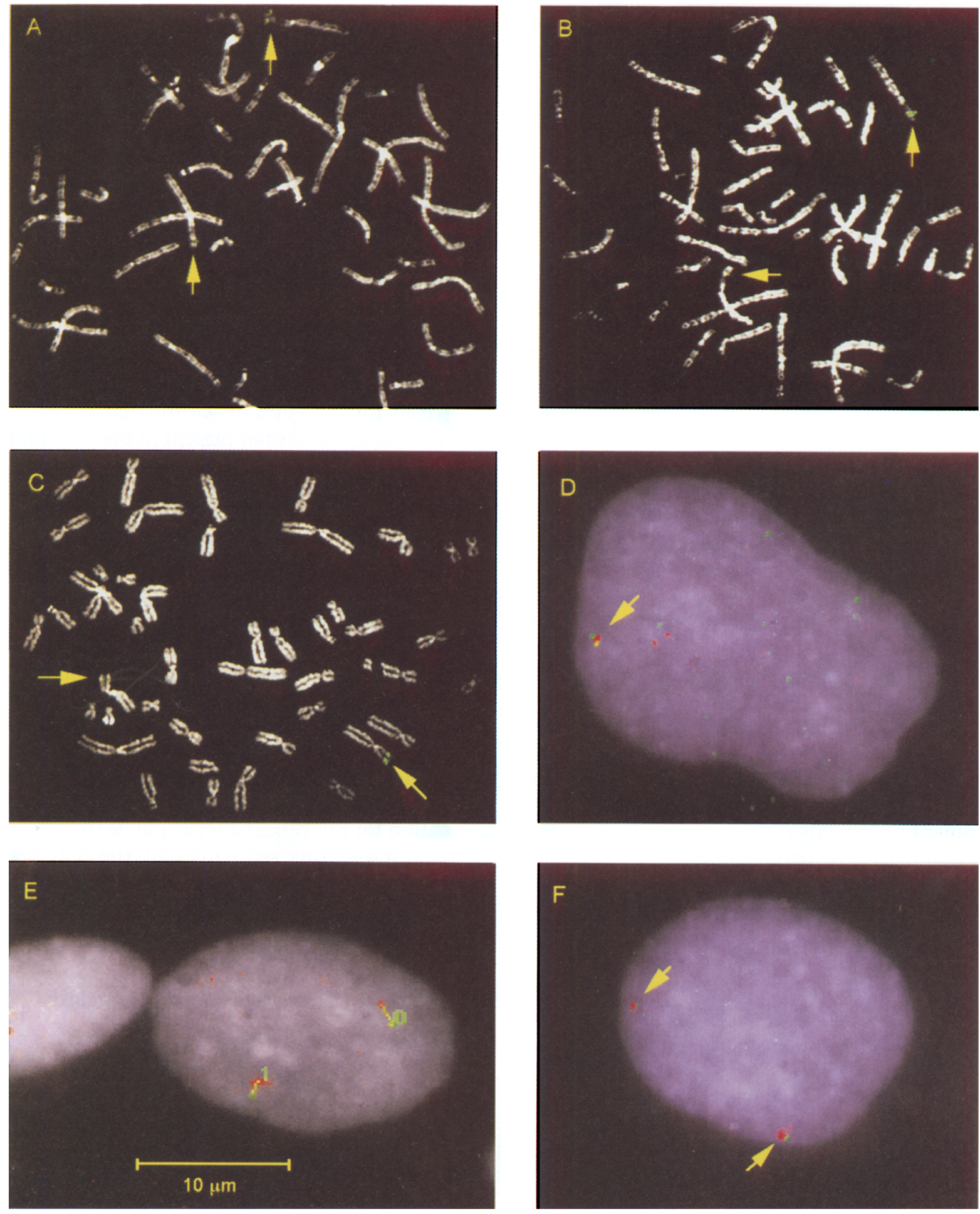

Figure $3 \mathrm{FISH}$ analysis of YAC and cosmid clones. YAC clones were mapped to G-bands at the 850-band level after image enhancement. (A) YAC $779 \mathrm{~d} 5$ mapped to the 6p23-p24.1 border; (B) YAC $798 \mathrm{f} 11$ to 6p23; and (C) YAC $759 \mathrm{f} 7$ to the $6 \mathrm{p} 22.3-\mathrm{p} 23$ border. (D) Interphase analysis was used to verify the order of cosmid clones 7N14, 23E6, and 45F20 (red, green, and yellow, respectively) and to ascertain the physical distances between them (see Results). Using the same technique, YAC pairs $923 \mathrm{~h} \_11$ and $798 \mathrm{f} 7(E)$ and $912 \mathrm{~g} 99$ and $798 \mathrm{f} 7(F)$ were shown to be separated by $450 \pm 61 \mathrm{~kb}$ and $<50 \mathrm{~kb}$, respectively. $E$ also illustrates the on-screen measurement of distances between signals (yellow dotted line between red and green signals) and a scale bar. 


\section{OLAVESEN ET AL.}

picked into 96-well plates. This sublibrary of clones was gridded onto new filters that were probed with the same YACs. Two hundred and sixty-four $(67 \%)$ of the cosmid clones were rescreened successfully with the original YACs and the names of these rescreened cosmids have been submitted to the Reference Library System Database (Zehetner and Lehrach 1994). The cosmid sublibrary filters were then probed with eight additional YACs (AM137_h_5, 773b_9, 798ff 7, 827 h 5,850 f 5,871 c 7,938 e_ 7 , and 982_e 7 ) derived from the same region as the YACs originally used to screen the chromosome 6 cosmid library (Figs. 4 and 5). Eight (3\%) of the cosmids were positive with all of the YACs used to screen the cosmid sub-library. Two of these cosmids (8I17 and 10A16) were used for FISH analysis of metaphase chromosomes and both signals were detected on the satellites, but not the centromeres, of all the D- and G-group chromosomes. By grouping the cosmids according to the YACs to which they hybridized it was possible to assign 252 of them to defined intervals overlapping and nonoverlapping between the YACs (Fig. 5; and Table 3). By this means 222 clones (84\%) of the successfully rescreened clones were assigned to 18 pockets each containing three or more cosmids.

Using a relatively high density of YACs across the region to screen the cosmid grids increased the resolution of the resulting cosmid pocket map, but also introduced ambiguities in the assignment of individual cosmids. The presence of internal deletions within some of the YACs and

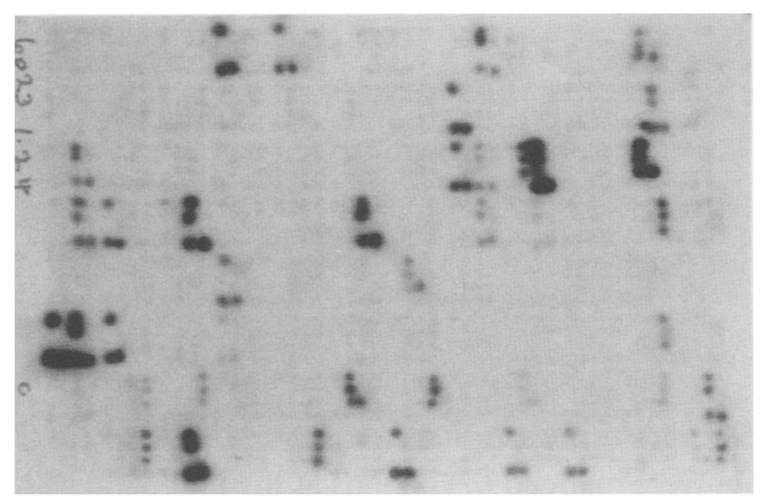

Figure 4 An example of hybridization of YAC $798 \mathrm{f} 7(E)$ in total yeast DNA to a cosmid sublibrary filter. The bacterial colonies from each 96-well microtiter plate were repeatedly spotted in different characteristic patterns to facilitate accurate scoring of positive clones. additional false-negative results were probably responsible for a number of pockets with only one or two cosmids that could not be positioned accurately on the map (Fig. 5).

To detect clones positive with PCR markers, DNA was prepared from multidimensional pools of the cosmid sublibrary. Twenty-seven PCR markers, from D6S1077 to EST00859 plus D6S285, were used to screen the sublibrary and selected cosmids subcloned from YAC AM137 h 5 (S.J.Broxholme, J.L.Wixon, and R.D. Campbell, unpubl.). Twenty-four of the markers were positive for one or more of the cosmids (Fig. 5 ). One of the three markers not present in any of the cosmids, D6S334, was also found to be absent from YAC AM149_a 2 that had been used to screen for the cosmids within that region. The other two markers not present in the cosmid sublibrary, D6S337 and EST02156, may be present in a region from which cosmids were not identified in the original screen or may not be present in the entire cosmid library. Some of the cosmid clones were found to contain more than one marker and this has allowed small contigs to be generated at different points across the pocket map. All of the cosmids containing STSs were present within the pockets expected from the STS content of the YACs with three exceptions. Cosmids 7A15, 8P9, and 12A13 contain STSs absent from YACs 982_e 7 (D) and 827_H 5 (G), although the cosmids themselves were positive when screened with the YACs. A possible explanation for this discrepancy could be the presence of homologous sequences in the YACs and cosmids resulting in false assignment of the cosmids to these pockets and is consistent with the observations of others (Nizetic et al. 1994a).

\section{Interphase FISH Analysis of 6p23 Cosmids}

Multicolor FISH analysis of cosmid clones on interphase chromosomes was used to establish the order of some of the clusters of markers on the pocket map. Cosmids 23E6 (containing D6S260), $7 \mathrm{~N} 14$ (containing D6S469 and SB1), and 45F20 (containing D6S259) were used for the analysis (see Fig. 3D). Cosmid c144, which contains D6S289 in addition to D6S469 and SB1, did not yield reproducible signals on interphase chromosomes. The observed order and separation of the probes is $23 \mathrm{E} 6-250 \pm 58 \mathrm{~kb}-7 \mathrm{~N} 14-100 \pm 50 \mathrm{~kb}-$ $45 \mathrm{~F} 20$.

This map is in agreement with the order of markers in the YAC contigs (see Fig. 2) (Banfi et 


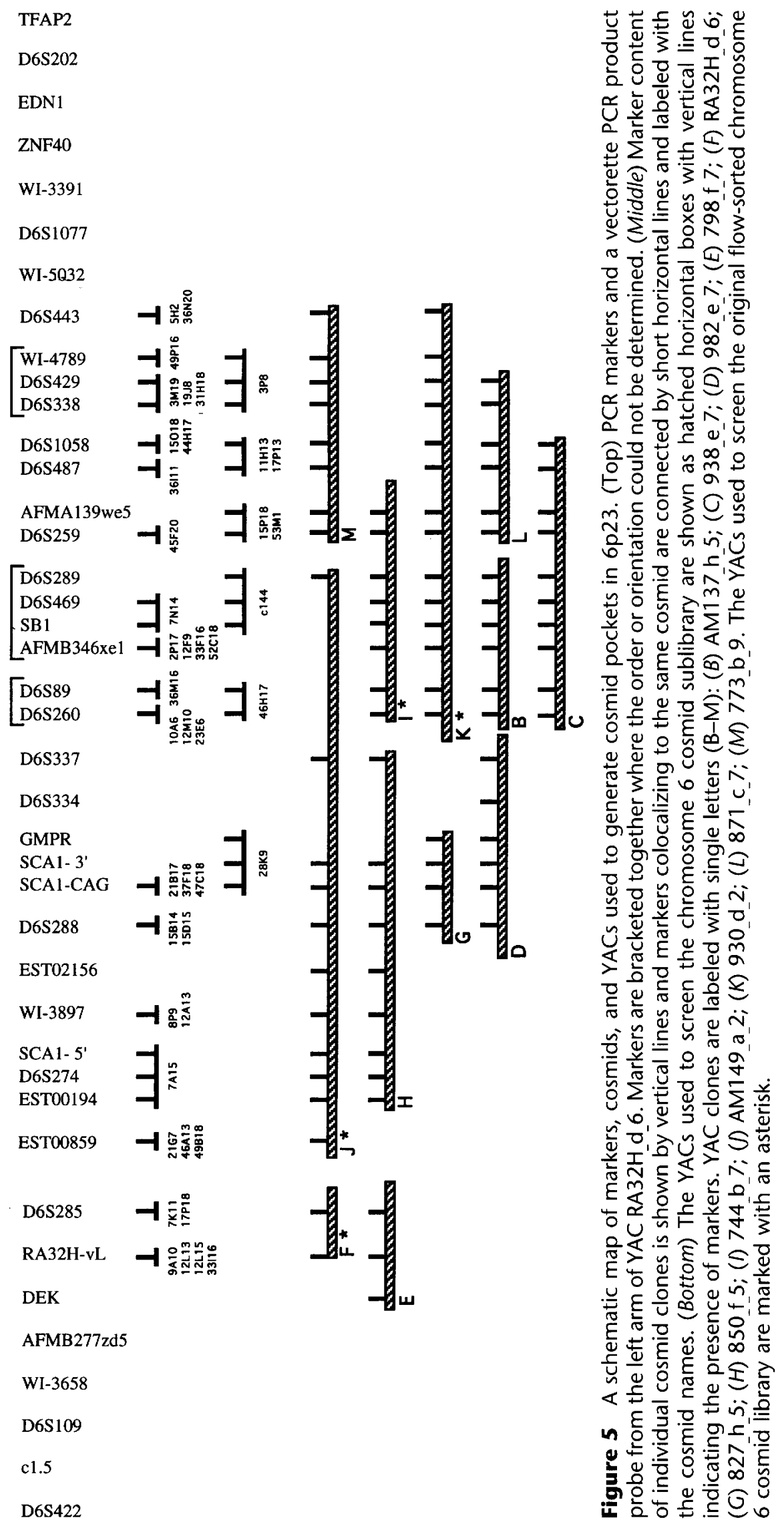


OLAVESEN ET AL.

Table 3. List of cosmid pockets in $6 \mathrm{p} 23$

\begin{tabular}{|c|c|c|c|c|c|c|c|c|c|c|c|c|c|c|c|}
\hline \multirow{2}{*}{\begin{tabular}{|l} 
Cosmid Pocket \\
BCIK \\
\end{tabular}} & \multicolumn{15}{|c|}{ Cosmid Names } \\
\hline & $5 \mathrm{~F} 14$ & $7 \mathrm{~N} 14$ & $10 \overline{A 6}$ & 11D22 & $12 \mathrm{M} 10$ & $19 \mathrm{G} 15$ & $23 \mathrm{E} 6$ & $27 \mathrm{E} 1$ & $36 \mathrm{M16}$ & $39 \mathrm{C} 4$ & $46 \mathrm{H} 17$ & $46 \mathrm{~N} 3$ & $47 \mathrm{~N} 13$ & $48 \mathrm{~K} 6$ & 53 D5 \\
\hline BK + BCK & 2P17 & $12 \mathrm{~F} 9$ & $27 J 18$ & $33 \mathrm{~F} 16$ & $44 \mathrm{M} 19$ & $52 \mathrm{C} 18$ & & & & & & & & & \\
\hline \multirow[t]{2}{*}{ C } & $1 \mathrm{H} 6$ & $3 \mathrm{C} 19$ & 3D24 & 4A15 & $4 G 16$ & $5 \mathrm{M} 20$ & $6 \mathrm{H} 19$ & $6 \mathrm{~L} 11$ & 7D3 & $7 \mathrm{~N} 14$ & $11 \mathrm{H} 13$ & $13 \mathrm{G} 10$ & $14 \mathrm{G} 5$ & $17 \mathrm{~B} 11$ & 19L3 \\
\hline & $20 \mathrm{C} 10$ & $20 \mathrm{~N} 24$ & $20 \mathrm{~J} 2$ & $26 \mathrm{Al} 10$ & $31 \mathrm{~A} 6$ & 3719 & $37 \mathrm{~N} 20$ & $38 \mathrm{E} 22$ & $43 \mathrm{H} 18$ & $43 \mathrm{~N} 8$ & $45 \mathrm{G} 9$ & $46 G 8$ & & & \\
\hline CIM & $15 \mathrm{~J} 18$ & $15 P 18$ & $27 \mathrm{G5}$ & $28 \mathrm{G} 21$ & $38 \mathrm{D} 13$ & $40 \mathrm{P} 1$ & $44 \mathrm{~K} 12$ & $45 \mathrm{~F} 20$ & $49 \mathrm{H} 11$ & $5 \overline{\mathrm{PPI}}$ & $53 \mathrm{M}$ & 54P22 & & & \\
\hline \multirow[t]{2}{*}{$\mathbf{C M}$} & $8 \mathrm{~B} 11$ & 9020 & $10 \mathrm{H} 21$ & $11 \mathrm{H} 13$ & $11 \mathrm{~N} 14$ & 13D16 & 15018 & $17 \mathrm{~B} 22$ & $17 \mathrm{G} 23$ & $17 \mathrm{P} 13$ & $31 \mathrm{~B} 5$ & $31 \mathrm{Cl}$ & $31 \mathrm{~F} 10$ & 36111 & $44 \mathrm{H} 17$ \\
\hline & $46 \mathrm{H} 6$ & $46 \mathrm{~N} 6$ & 47E5 & 5218 & & & & & & & & & & & \\
\hline DGHJ & $7 \mathrm{C} 6$ & $15 \mathrm{~B} 14$ & 15D15 & $32 \mathrm{~L} 5$ & $33 \mathrm{~B} 19$ & $37 \mathrm{~A} 10$ & $40 \mathrm{M} 17$ & 43020 & $52 \mathrm{~L} 22$ & & & & & & \\
\hline DGJ & $7 \mathrm{~A} 15$ & $21 \mathrm{~J} 10$ & $28 \mathrm{~K} 22$ & $35 \mathrm{~L} 3$ & $54 \mathrm{G} 10$ & & & & & & & & & & \\
\hline$\overline{\mathbf{D K}}$ & $9 \mathrm{P} 1$ & $17 \mathrm{C} 19$ & $22 \mathrm{C} 17$ & $28 \mathrm{~N} 8$ & 50016 & & & & & & & & & & \\
\hline \multirow[t]{3}{*}{$\mathbf{E F}$} & 117 & 1115 & $3 \mathrm{M} 18$ & $5 \mathrm{E} 1$ & $5 \mathrm{~N} 3$ & $7 \mathrm{~K} 11$ & $8 \mathrm{P} 13$ & $9 \mathrm{~A} 10$ & $12 \mathrm{F7}$ & $12 \mathrm{~L} 13$ & 12L.15 & $14 \mathrm{H} 20$ & $17 \mathrm{P} 18$ & $21 \mathrm{~F} 8$ & $25 \mathrm{P} 2$ \\
\hline & $26 \mathrm{~A} 7$ & $28 \mathrm{D} 22$ & 29P9 & $32 \mathrm{H} 12$ & $32 \mathrm{~J} 15$ & 33116 & $35 \mathrm{~A} 16$ & $36 \mathrm{E} 6$ & $36 \mathrm{E} 8$ & $41 \mathrm{G} 9$ & $47 \mathrm{~L} 19$ & $50 \mathrm{~A} 17$ & $50 \mathrm{~J} 18$ & $50 \mathrm{~J} 20$ & $51 \mathrm{E} 11$ \\
\hline & $52 \mathrm{D} 12$ & 52E22 & $52 \mathrm{~K} 3$ & & & & & & & & & & & & \\
\hline GHJ & 21817 & $25 \mathrm{~F} 8$ & $28 \mathrm{~K} 9$ & $37 \mathrm{~F} 18$ & $40 \mathrm{C} 15$ & $47 \mathrm{C} 18$ & 4908 & & & & & & & & \\
\hline \multirow[t]{3}{*}{ GJ } & $1 \mathrm{~N} 17$ & $3 \mathrm{F7}$ & $4 \mathrm{~F} 18$ & $4 \mathrm{H} 3$ & 4018 & $6 \mathrm{G} 21$ & $6 \mathrm{~K} 6$ & $8 P 9$ & 9118 & $10 C 11$ & $12 \mathrm{~A} 13$ & $12 \mathrm{~A} 22$ & $13 P 23$ & $16 \mathrm{~K} 14$ & $18 \mathrm{Cl9}$ \\
\hline & $19 L 13$ & 22D19 & $23 \mathrm{~A} 22$ & $24 \mathrm{~L} 15$ & $26 \mathrm{~A} 13$ & 28D6 & $36 \mathrm{Cl}$ & $38 \mathrm{~B} 22$ & $38 \mathrm{~F} 12$ & $39 \mathrm{~B} 10$ & $40 \mathrm{~K} 14$ & $45 \mathrm{~A} 8$ & $45 \mathrm{~K} 14$ & $45 \mathrm{~L} 16$ & $45 \mathrm{M} 11$ \\
\hline & 45011 & $45 \mathrm{P} 11$ & $46 \mathrm{~K} 12$ & $46 \mathrm{~N} 22$ & $47 \mathrm{~N} 3$ & $48 \mathrm{~A} 11$ & $48 \mathrm{~A} 8$ & $48 \mathrm{C} 13$ & 51D10 & & & & & & \\
\hline IK & $14 \mathrm{H} 4$ & $18 \mathrm{I} 7$ & $18 \mathrm{~K} 12$ & 19014 & $20 \mathrm{C} 8$ & $25 \mathrm{~K} 11$ & $32 \mathrm{F5}$ & $40 \mathrm{Cl} 14$ & $40 I 4$ & & & & & & \\
\hline $\mathbf{J}$ & $10 \mathrm{E} 8$ & $21 \mathrm{G} 7$ & $25 \mathrm{~A} 13$ & $27 \mathrm{C} 4$ & $27 \mathrm{M} 23$ & 39G13 & $39 \mathrm{~N} 5$ & 43D23 & $46 \overline{\mathrm{A} 13}$ & $47 \mathrm{C} 17$ & $49 \mathrm{~B} 18$ & $52 \mathrm{~F} 10$ & 5212 & $53 \mathrm{H} 17$ & 53018 \\
\hline \multirow[t]{2}{*}{ IK } & $6 \mathrm{~K} 22$ & 11013 & $15 \mathrm{~A} 20$ & $18 J 16$ & $37 \mathrm{D} 17$ & $38 \mathrm{~J} 23$ & $39 \mathrm{G} 18$ & $39 \mathrm{~J} 1$ & $40 \mathrm{E} 15$ & $42 \mathrm{~L} 18$ & $43 \mathrm{E} 18$ & $47 \mathrm{M} 7$ & 47012 & $49 \mathrm{H} 12$ & $51 \mathrm{C} 4$ \\
\hline & $51 \mathrm{~J} 4$ & $52 \mathrm{H}^{9}$ & & & & & & & & & & & & & \\
\hline \multirow[t]{2}{*}{$\overline{\mathbf{K}}$} & $1 \mathrm{H} 22$ & $3 \mathrm{~A} 14$ & $4 \mathrm{H} 16$ & $8 \mathrm{~J} 22$ & $10 \mathrm{~A} 10$ & 1318 & $21 \mathrm{~A} 21$ & $32 \mathrm{~J} 4$ & $35 \mathrm{G} 7$ & $39 \mathrm{~K} 18$ & $43 \mathrm{E} 19$ & $45 \mathrm{F8}$ & $45 \mathrm{~N} 16$ & $46 \mathrm{P} 2$ & $48 \bar{A} 15$ \\
\hline & 53E20 & $53 \mathrm{~L} 15$ & & & & & & & & & & & & & \\
\hline KLM & 2116 & $3 \mathrm{M} 19$ & & & & & & & & & & & & & \\
\hline $\mathbf{K M}$ & 3P8 & $5 \mathrm{H} 2$ & $15 \mathrm{Al} 5$ & 1718 & $19 \mathrm{~J} 8$ & $19 \mathrm{P} 1$ & 22B14 & $31 \mathrm{H} 18$ & $36 \mathrm{~N} 20$ & 37E3 & $38 \mathrm{G} 12$ & 39D19 & $42 \mathrm{P} 1$ & 43P15 & 49P16 \\
\hline
\end{tabular}

The pockets are defined by overlapping and nonoverlapping YAC clones (labeled B-M): AM137_h_5 (B), $938 \_e \_7$ (C), 982_e_7 (D), 798_f_7 (E), RA32H_d_6 (F), 827_h_5 (G), 850_f_5 (H), 744_b_7 (I), AM149_a_2 (J), 930_d_2 (K), 871_c_7 (L) and 773_b_9 (M).

al. 1993) and the EUROGEM genetic map order (Terrenato et al. 1994) of CEN-D6S260-D6S289D6S259-TEL, which places D6S289 distal of D6S260 by virtue of a single recombination event. The physical maps (Nemani et al. 1994; Volz et al. 1994) have the order CEN-D6S289(D6S89, D6S260)-TEL, probably as result of internal deletions within YACs. The direct physical mapping of uncloned DNA by interphase FISH analysis avoids this possible source of error and is in agreement with the genetic mapping data.

\section{An Integrated Map of $6 \mathrm{p} 23$}

The construction of the YAC contig spanning the chromosomal region from $6 \mathrm{p} 22.3$ to $6 \mathrm{p} 24.1$ used a number of markers from diverse sources such as genetic maps (Weissenbach et al. 1992; Jodice et al. 1993; Kwiatkowski et al. 1993; Gyapay et al.
1994), genes and anonymous ESTs mapped to the region (Arinami et al. 1991; Gaynor et al. 1991a,b; von Lindern et al. 1992; Orr et al. 1993; Banfi et al. 1994; Murano et al. 1994; Pappas et al. 1995), and anonymous markers from the Whitehead Institute/MIT Genome Center Database and Genome Data Base (GDB), as well as the subcloned Alu-PCR products. In addition, 25 of the PCR markers were mapped to cosmids within the pocket map thereby increasing the resolution of the overall map and resolving some of the markers not separated by the YACs. All of the markers have been incorporated into a single physical map thereby integrating genetic, physical, and transcriptional mapping data.

The map contains three anonymous ESTs whose location can now be integrated with the genetic maps and positioned relative to the other genes. At least one of the anonymous ESTs 
(EST02156) is located between the STSs at the $5^{\prime}$ and 3 ' ends of the SCA1 gene and therefore, must lie within the SCA1 gene. Another anonymous EST (EST00194) cannot be resolved from the marker at the $5^{\prime}$ end of the SCA1 gene, or D6S274, and therefore, this expressed sequence may also lie within the SCA1 gene. The sequences of both these ESTs have been compared with the published sequence of the SCA1 gene (Banfi et al. 1994) and no sequence simmilarity was observed.

\section{DISCUSSION}

We have constructed an integrated map of human chromosome $6 \mathrm{p} 23$ consisting of YAC and cosmid clones, polymorphic genetic markers, anonymous STSs and ESTs, anonymous subcloned Alu PCR products, and known genes. Both PCR screening and hybridization probing were used to determine the relationships between the YAC clones. This allowed both the previously published STS markers and the new markers, generated by subcloning Alu PCR products and STSs designed from known genes, to be used to characterize the same set of YAC clones.

The cosmid pocket map was constructed by hybridizing whole yeast DNA-containing YACs to arrayed grids of cosmids thereby removing the need to purify the YAC DNA away from the host yeast chromosomes. The map has been used to facilitate the construction of individual regionspecific cosmid contigs derived from the pockets (M.G. Olavesen, unpubl.) that can be expanded to generate longer range contigs (S.J. Broxholme, J.L. Wixson, and R.D. Cambell, unpubl.). Meanwhile, some of the cosmids were found to contain one or more markers allowing small contigs to be formed, increasing the resolution of the map, and allowing some markers to be resolved. In addition, the data from the cosmid pocket map has been used to select cosmids distributed across the region for use as probes for long-range mapping of 6 p23 (J.L. Wixon and R.D. Campbell, unpubl.).

To verify the physical map derived from the cloned resources of YACs and cosmids we have carried out FISH analysis on uncloned DNA from metaphase and interphase chromosomes. This proved particularly useful to check that the YACs used for Alu PCR to generate additional markers were not chimeric and to confirm that YACs positive for any of the anonymous STSs not genetically linked to chromosome 6 were derived from the region of interest. In addition, analysis of YACs on interphase chromosomes allowed gaps in the contig to be monitored to facilitate closure and also confirmed the physical order of cosmids to be determined on uncloned DNA.

The contiguous resource of YAC clones now spans from $6 \mathrm{p} 22.3$ to distal $6 \mathrm{p} 24.3$ (Davies et al. 1995; R.J. Stephens and J. Ragoussis, unpubl.). This is an invaluable resource for cytogenetic investigation of distal $6 \mathrm{p}$ as well as mapping of new markers in the region. The YAC clones can also be used to extend the YAC to cosmid contig conversion so that the cosmid resources can be used for more detailed physical mapping as well as gene detection and transcript mapping in 6p22.3-p24.3.

The integrated map contains 55 markers, spanning the region from $6 \mathrm{p} 22.3$ to $6 \mathrm{p} 24.1$ that covers 7.5-8.5 Mb, including the entire $6 \mathrm{p} 23$ band. Twenty of the markers on the map are polymorphic genetic markers (Weissenbach et al. 1992; Jodice et al. 1993; Kwiatkowski et al. 1993; Gyapay et al. 1994). Their integration into a single map has increased the marker density and ordered the markers to facilitate the generation of haplotypes for fine genetic mapping of the nonsyndromic CL/P (Carinci et al. 1995) and schizophrenia (Wang et al. 1995) loci mapped to the $6 \mathrm{p} 23$ region.

Six genes, DEK, SCA1, GMPR, ZNF40, EDN1, and TFAP2, and three anonymous ESTs are included in the map, thereby generating a preliminary transcription map of $6 \mathrm{p} 23$. It is unclear whether all three of the ESTs represent new genes in 6 p23 because one lies within the SCA1 gene and another lies in very close proximity to the $5^{\prime}$ end of the SCA1 gene. The distribution of the genes and ESTs appears to be clustered into two groups. The first group of genes is located at the distal end of the contig and consists of ZNF40, EDN1, and TFAP2. The second group is flanked by the DEK and GMPR genes and includes the SCA1 gene. EST00194 lies within the same cosmid as the $5^{\prime}$ end of the SCA1 gene, EST02156 lies within the SCA1 gene, although neither EST appears to be part of the published SCA1 sequence, and GMPR lies immediately adjacent to the 3' end of the SCA1 gene. The close proximity of these genes and ESTs supports the suggestion that $6 \mathrm{p} 23$ may be gene dense.

The locations of the genes and ESTs have been integrated with the genetic markers and this could facilitate their use in any positional cloning studies. 
OLAVESEN ET AL.

\section{METHODS}

\section{Probes, PCR Primers, and Conditions}

All STS markers used the same PCR conditions with the exception of the annealing temperature $\left(T_{\mathrm{ann}}\right)$, which was optimized for each primer set. The standard conditions used were $94^{\circ} \mathrm{C}$ for $4 \mathrm{~min}$, then 35 cycles of $94^{\circ} \mathrm{C}$ for $30 \mathrm{sec}$, $30 \mathrm{sec}$ at $T_{\mathrm{ann}}, 72^{\circ} \mathrm{C}$ for $30 \mathrm{sec}$ followed by $72^{\circ} \mathrm{C}$ for $2 \mathrm{~min}$. The PCR was carried out in $50 \mathrm{~mm} \mathrm{KCl}, 10 \mathrm{~mm}$ Tris-HCl (pH 9.0), $1.5 \mathrm{mM} \mathrm{MgCl}_{2} 0.1 \%$ Triton X-100, 0.2 mM dNTPs, $1 \mu \mathrm{M}$ of each primer (unless stated otherwise), and 0.5 units of Taq DNA polymerase in a $10-\mu$ l reaction.

Primers for D6S89 $\left(T_{\text {ann }}=56^{\circ} \mathrm{C}\right)$ (Litt and Luty 1990), D6S109 $\left(T_{\mathrm{ann}}=62^{\circ} \mathrm{C}\right)$ using $0.1 \mu \mathrm{M}$ primer 15a (Ranum et al. 1991), D6S202 $\left(T_{\text {ann }}=52^{\circ} \mathrm{C}\right)$ using primer set pHZ-30/ 2.6 (Le Borgne-Demarquoy et al. 1991), D6S334 $\left(T_{\mathrm{ann}}=56^{\circ} \mathrm{C}\right)($ Orphanos et al. 1994$), \mathrm{SB} 1\left(T_{\mathrm{ann}} \equiv 56^{\circ} \mathrm{C}\right)$, AM $10 \mathrm{GA} / \mathrm{D} 6 \mathrm{~S} 337\left(T_{\mathrm{ann}}=61^{\circ} \mathrm{C}\right), \quad \mathrm{LR} 40 / \mathrm{D} 6 \mathrm{~S} 338$ $\left(T_{\mathrm{ann}}=60^{\circ} \mathrm{C}\right)$ using primer set $\mathrm{A}$ (Kwiatkowski et al. 1993), EST00301/D6S315E $\left(T_{\text {ann }}=56^{\circ} \mathrm{C}\right)$, EST02534/D6S316E $\left(T_{\mathrm{ann}}=58^{\circ} \mathrm{C}\right)$, EST00798/D6S321E $\left(T_{\mathrm{ann}}=54^{\circ} \mathrm{C}\right)$, EST00194/D6S324E $\left(T_{\text {ann }}=58^{\circ} \mathrm{C}\right)$, EST00449/D6S328E $\left(T_{\text {ann }}=52^{\circ} \mathrm{C}\right)$, EST02156/D6S1385E $\left(T_{\text {ann }}=54^{\circ} \mathrm{C}\right)$, EST00859/D6S1394E $\left(T_{\mathrm{ann}}=54^{\circ} \mathrm{C}\right)$ (Pappas et al. 1995) and D6S259 $\left(T_{\mathrm{ann}}=58^{\circ} \mathrm{C}\right)$ using $0.5 \mu \mathrm{M}$ of each primer, D6S260 $\left(T_{\text {ann }}=52^{\circ} \mathrm{C}\right)$, D6S274 $\left(T_{\text {ann }}=56^{\circ} \mathrm{C}\right)$, D6S285 $\left(T_{\text {ann }}=66^{\circ} \mathrm{C}\right), \quad$ D $6 S 288\left(T_{\text {ann }}=54^{\circ} \mathrm{C}\right)$, D $6 S 289$ $\left(T_{\mathrm{ann}}=56^{\circ} \mathrm{C}\right)$, D $6 \mathrm{~S} 422\left(T_{\mathrm{ann}}=53^{\circ} \mathrm{C}\right)$, D $6 \mathrm{~S} 429$ $\left(T_{\mathrm{ann}}=59^{\circ} \mathrm{C}\right)$, D $6 \mathrm{~S} 443\left(T_{\mathrm{ann}}=56^{\circ} \mathrm{C}\right)$, D $6 \mathrm{~S} 469$ $\left(T_{\text {ann }}=62^{\circ} \mathrm{C}\right)$ from the Genethon genetic maps (Weissenbach et al. 1992; Gyapay et al. 1994). Primers for D6S1058 $\left(T_{\text {ann }}=52^{\circ} \mathrm{C}\right)$, D6S1077/WI-2369 $\left(T_{\text {ann }}=56^{\circ} \mathrm{C}\right)$, D6S1301/ WI-4789 $\left(T_{\text {ann }}=58^{\circ} \mathrm{C}\right)$, WI-3391 $\left(T_{\text {ann }}=58^{\circ} \mathrm{C}\right)$, WI-3658 $\left(T_{\mathrm{ann}}=54^{\circ} \mathrm{C}\right)$, WI $-3897\left(T_{\mathrm{ann}}=56^{\circ} \mathrm{C}\right)$, WI-5032 $\left(T_{\mathrm{ann}}=54^{\circ} \mathrm{C}\right)$, AFMA139we5 $\left(T_{\mathrm{ann}}=50^{\circ} \mathrm{C}\right)$, AFM268vh5 $\left(T_{\mathrm{ann}}=60^{\circ} \mathrm{C}\right), \mathrm{AFMB} 277 \mathrm{zd} 5\left(T_{\mathrm{ann}}=56^{\circ} \mathrm{C}\right)$, AFM346xe 1 $\left(T_{\mathrm{ann}}=56^{\circ} \mathrm{C}\right)$ were taken from the Whitehead Institute/ MIT Genome Center Data Release 7. Data for D6S487 $\left(T_{\mathrm{ann}}=64^{\circ} \mathrm{C}\right)$ were obtained from GDB version 5.5.1. Primers for STS $\mathrm{c} 1.5$ were $\mathrm{c} 1.5 \mathrm{~A}$ 5'-CAGATGCTATGCTTCAC- $3^{\prime}$ and c1.5B 5'-CCAACAGATGGGTTTAG-3' $\left(T_{\mathrm{ann}}=52^{\circ} \mathrm{C}\right.$ (P. Malaspina, A. Novelletto, and L. Terrenato, pers. comm.).

ESTs for TFAP2 and EDN1 genes were as described previously (Davies et al. 1995). Primers for DEK (von Lindern et al. 1992) were DEKL 5'-GAGCTAATTTCTTGAGATAGAGG-3' and DEKR $5^{\prime}$-GGAACAATTAATGCCATGCAAG-3' $\left(T_{\text {ann }}=56^{\circ} \mathrm{C}\right)$, for ZNF40 (HIV-EP1/MBP-1/ PRDII-BF1) (Gaynor et al. 1991a) were PRDII 5' 5'CTCATGACTAATCTTTGTGC-3' and PRDII $3^{\prime} 5^{\prime}$ CTTACACAAGGAGGACAGAC- $3^{\prime}\left(T_{\text {ann }}=56^{\circ} \mathrm{C}\right)$, and for GMPR (Kondoh et al. 1991) were GMPR-5' 5' GTTCTATCGTCTTCCAGAGCC-3' and GMPR-3' 5'GAGGTTATGAGTTCTGGGCAG-3'. For the SCA1 gene the $(C A G)_{n}$ repeat was amplified with the Pre-1 and Rep-2 primers (Orr et al. 1993). Primers for the ends of the SCA1 gene (Banfi et al. 1994) were SCA1 5'f $5^{\prime}$ CAGTGGCGGACGTACAGG-3' and SCA1 5'r 5'GTAAATGGATCTGGGGTTGC- $3^{\prime}\left(T_{\mathrm{ann}}=59^{\circ} \mathrm{C}\right)$ and SCA1 3'f 5'-CTGACATGGCCAGTACAGAG-3' and SCA1 3'r 5'CCTACAAATAGACACACCACG $-3^{\prime}\left(T_{\mathrm{ann}}=59^{\circ} \mathrm{C}\right)$.

Hybridization probes for the human renal sodium phosphate transport protein gene (NPT1/SLC17A1) (Chong et al. 1993) and the human FIM1 gene (Van Cong et al. 1989) were used to screen YAC and cosmid clones isolated from primary library screens.

\section{Isolation and DNA Preparation of YAC and Cosmid Clones}

YAC clones were isolated by PCR-only screening of the CEPH (Dausset et al. 1992), ICRF (Larin et al. 1991) and ICI (Anand et al. 1991) YAC libraries based on the strategy of Green and Olson (1990). Agarose blocks of yeast DNA were prepared by the method described in Southern et al. (1987) and total yeast DNA was isolated from the blocks as described in Davies et al. (1995). High density membranes of the flow-sorted chromosome 6 cosmid library (Nizetic et al. 1991, 1994b) were screened with YACs by hybridization of total yeast DNA using total human DNA to suppress signals from repetitive sequences (Sealey et al. 1985). YAC and cosmid clones selected from primary library screens were gridded onto membranes using a Beckman Biomek 1000 -robot and processed as described in Bentley et al. (1992). Clones were arrayed in characteristic patterns to facilitate precise identification of coordinates on filters. Cosmid DNA was prepared by alkaline lysis followed by binding of the DNA to silica as described in Carter and Milton (1993). Additional cosmids subcloned from YAC AM137 h_5 into the SuperCos 1 vector (J.L. Wixon, S.J. Broxholme, and R.D. Campbell, unpubl.), prefixed with " $c$ " were used where clones had not been obtained from the flow-sorted chromosome 6 cosmid library.

The clones described are available upon request. In addition, the ICI, ICRF, and CEPH YAC library clones are available from the U.K. Human Genome Mapping Project (HGMP)-Resource Centre, the chromosome 6 cosmids and the ICRF YAC library clones are available through the Reference Library Database System and the CEPH YAC library clones are available from CEPH.

\section{Preparation of Alu PCR and Vectorette PCR Probes for Hybridizations}

Inter-Alu PCR was carried out using the ALE1 and ALE3 primers (Cole et al. 1992) in $50 \mathrm{~mm} \mathrm{KCl}, 10 \mathrm{~mm}$ Tris- $\mathrm{HCl}$ (pH 9.0), $7.5 \mathrm{~mm} \mathrm{MgCl}_{2}, 0.1 \%$ Triton X-100, $0.2 \mathrm{~mm}$ dNTPs, $1 \mu \mathrm{M}$ each primer, and 0.5 units of Taq DNA polymerase in a $10-\mu \mathrm{l}$ reaction. The PCR conditions used were: $94^{\circ} \mathrm{C}$ for $4 \mathrm{~min}$, then 35 cycles of $94^{\circ} \mathrm{C}$ for $1 \mathrm{~min}, 63^{\circ} \mathrm{C}$ for $1 \mathrm{~min}, 72^{\circ} \mathrm{C}$ for $3 \mathrm{~min}$, followed by $72^{\circ} \mathrm{C}$ for $5 \mathrm{~min}$. Amplified products were purified using silica particles (Carter and Milton 1993) and shotgun cloned into the PCR II vector (Invitrogen). Hybridization probes were isolated from individual clones after excision of the inserts from the vector DNA with EcoRI. Vectorette PCR was carried out as described (Riley et al. 1990) using the restriction enzymes RsaI, AluI, and PvuII on total yeast DNA isolated from blocks. All Alu PCR and vectorette PCR probes were hybridized in the presence of total human DNA to suppress signals from repetitive sequences (Sealey et al. 1985).

\section{Fluorescence in situ Hybridization}

FISH mapping of YACs and cosmids was performed on metaphase chromosomes prepared from phytohemagglu- 
tinin (PHA)-stimulated peripheral blood lymphocytes from healthy men. These were synchronized with thymidine, lysed and harvested by standard cytological techniques (Rooney and Czepulkowski 1992).

YAC clones were not isolated from endogenous yeast DNA before FISH. Cosmid clones, total yeast DNA, and Alu PCR products were labeled with biotin-14-dATP or digoxigenin-11-dUTP by nick translation (Bio-Nick Labelling System or Nick Translation System, respectively, BRL Life Technologies, USA). Probes requiring double-labeling were prepared by mixing equal quantities of biotin- and digoxigenin-labeled probe.

In situ hybridization was performed as described (Adinolfi and Davies 1994). YAC or cosmid probes (50 or $100 \mathrm{ng}$ per slide, respectively) were prehybridized with Cot-1 DNA $(50 \times(w t / w t))$ before FISH. Hybridization signals from biotin-labeled probes were developed using alternate layers of avidin-fluorescein isothiocyanate (avidin-FITC) and biotinylated anti-avidin. Those from digoxigenin-labeled probes were developed with a layer of sheep anti-digoxigenin conjugated to tetramethylrhodamine isothiocyanate (TRITC-anti-digoxigenin) followed by one layer of TRITC-conjugated donkey antisheep (The Binding Site, Birmingham, UK). Slides were mounted in Vectashield antifading medium (Vector Laboratories, Peterborough, UK) containing $80 \mathrm{ng} / \mathrm{ml}$ of 4', 6-diamidino-2-phenylindole (DAPI) as counterstain. Signals were visualised under a Zeiss Axioplan microscope equipped with a cooled charge-coupled device (CCD) camera (Photometrics, Woburn, MA) and Smartcapture image analysis system (Digital Scientific Instruments, Cambridge, UK). FITC, TRITC, and DAPI images were captured using filters four, three, and two of the Pinkel filter wheel 1 , respectively. G-banding was enhanced during image analysis.

YAC and cosmid clones were mapped to specific chromosome bands by examination of a minimum of 10 wellextended metaphases per clone. The quality of the banding was sufficient to allow localization of clones to precise bands and subbands by comparison with the digitized and differentially shaded ideograms, at the 850 -band level, as depicted by Francke (1994).

Interphase FISH was performed on nuclei prepared from fibroblasts that had been grown to confluence and, therefore, were in $G_{1}$ phase. In the absence of a wellcharacterized cosmid contig from $6 \mathrm{p} 23$ the nuclei were calibrated using cosmid pairs from the human $\mathrm{MHC}$ in 6 21.3 of known distance separation (Carroll et al. 1984; Sargent et al. 1989; Kendall et al. 1990) as previously described (Senger et al. 1993) to obtain a calibration curve of physical distance $(\mathrm{kb})$ against measured distance $(\mu \mathrm{m})$. The calibration curve had a region of linearity between 50 and $500 \mathrm{~kb}$ and was therefore, was used to estimate distances between key cosmids and YACs in experiments using two or more differentially labeled clones. Clone pairs separated by distances $>500 \mathrm{~kb}$ could only be ordered using this technique and especially chosen sets of clones could be used to ascertain contig orientation. Physical distances were estimated from a minimum of 15 measurements per probe set and were normally taken from 25 or more measurements depending on the quality of signals obtained. Possible differences between the region of the genome used to generate the calibration curve and 6 p 23 may result in some variation between the actual distances and the distances we have estimated.

\section{ACKNOWLEDGMENTS}

We are grateful to Patrizia Malaspina, Andrea Novelletto, and Luciano Terrenato (University "Tor Vergata," Rome, Italy) for primers and cooperation with data exchange, Hans Lehrach (Max Planck Institute, Berlin, Germany) for making the chromosome 6 cosmid library available to us, David Bentley (Sanger Centre, Cambridge, UK) for organizing the YAC libraries, and Ruth Mason for excellent technical assistance. We thank the cytogeneticists of the S.E. Thames Regional Genetics Centre, Guy's Hospital for cell cultures, Denise Sheer (ICRF, London, UK) for advice in FISH techniques, and Martin Bobrow for encouragement and interest. M.G.O. is a recipient of a Medical Research Council (MRC) Special Training Fellowship, G.S. held an European Molecular Biology Organization postdoctoral fellowship, and J.L.W. held an MRC-HGMP Studentship. This work was supported by MRC-HGMP grants G9230373 and E227/24, European Economic Community (EEC) grant CT-93-0075, and Guy's Hospital Special Trustees.

The publication costs of this article were defrayed in part by payment of page charges. This article must therefore be hereby marked "advertisement" in accordance with 18 USC section 1734 solely to indicate this fact.

\section{REFERENCES}

Adinolfi, M. and A.F. Davies 1994. Non-isotopic in-situ hybridisation. Applications to clinical diagnosis and molecular genetics. R.G. Landes Co., Austin, TX.

Anand, R., D.J. Ogilvie, R. Butler, J.H. Riley, R.S. Finniear, S.J. Powell, J.C. Smith, and A.F Markham. 1991. A yeast artificial chromosome contig encompassing the cystic fibrosis locus. Genomics 9: 124-130.

Arinami, T., M. Ishikawa, A. Inoue, M. Yanagisawa, T. Masaki, M.C. Yoshida, and H. Hamaguchi. 1991. Chromosomal assignments of the human endothelin family genes: The endothelin-1 gene (EDN1) to $6 \mathrm{p} 23-\mathrm{p} 24$, the endothelin-2 gene (EDN2) to $1 \mathrm{p} 34$, and the endothelin-3 gene (EDN3) to 20q13.2-q13.3. Am. J. Hum. Genet. 48: 990-996.

Banfi, S., M.Y. Chung, T.J. Kwiatkowski Jr., L.P. Ranum, A.E. McCall, A.C. Chinault, H.T. Orr, and H.Y. Zoghbi. 1993. Mapping and cloning of the critical region for the spinocerebellar ataxia type 1 gene (SCA1) in a yeast artificial chromosome contig spanning $1.2 \mathrm{Mb}$. Genomics 18: $627-635$.

Banfi, S., A. Servadio, M.Y. Chung, T.J. Kwiatkowski Jr., A.E. McCall, L.A. Duvick, Y. Shen, E.J. Roth, H.T. Orr, and H.Y. Zoghbi. 1994. Identification and characterization of the gene causing type 1 spinocerebellar ataxia. Nature Genet. 7: 513-520.

Bentley, D.R., C. Todd, J. Collins, J. Holland, I. Dunham, S. Hassock, A. Bankier, and F. Giannelli. 1992. The development and application of automated gridding for efficient screening of yeast and bacterial ordered libraries. Genomics 12: 534-541. 


\section{OLAVESEN ET AL.}

Campbell, R.D. and J. Trowsdale. 1993. Map of the human MHC. Immunol. Today 14: 349-352.

Carinci, F., F. Pezzetti, L. Scapoli, E. Padula, U. Baciliero, C. Curioni, and M. Tognon. 1995. Nonsyndromic cleft lip and palate: evidence of linkage to a microsatellite marker on 6p23. Am. J. Hum. Genet. 56: 337-339.

Carroll, M.C., R.D. Campbell, D.R. Bentley, and R.R Porter. 1984. A molecular map of the human major histocompatibility complex class III region linking complement genes $\mathrm{C} 4, \mathrm{C} 2$ and factor B. Nature 307: 237-241.

Carter, M.J. and I.D. Milton. 1993. An inexpensive and simple method for DNA purifications on silica particles. Nucleic Acids Res. 21: 1044.

Chong, S.S., K. Kristjansson, H.Y. Zoghbi, and M.R. Hughes. 1993. Molecular cloning of the CDNA encoding a human renal sodium phosphate transport protein and its assignment to chromosome 6p21.3-p23. Genomics 18: $355-359$.

Cohen, D., I. Chumakov, and J. Weissenbach. 1993. A first-generation physical map of the human genome. Nature 366: 698-701.

Cole, C.G., I. Dunham, A.J. Coffey, M.T. Ross, S. Meier-Ewert, M. Bobrow, and D.R. Bentley. 1992. A random STS strategy for construction of YAC contigs spanning defined chromosomal regions. Genomics 14: $256-262$.

Craig, J.M. and W. A. Bickmore. 1993. Chromosome bands - Flavours to savour. Bioessays 15: 349-354.

Dausset, J., P. Ougen, H. Abderrahim, A. Billault, J.L. Sambucy, D. Cohen, and D. Le Paslier. 1992. The CEPH YAC library. Behring Inst. Mitt. 91: 13-20.

Davies, A.F., R.J. Stephens, M.G. Olavesen, L. Heather, M.J. Dixon, A. Magee, F. Flinter, and J. Ragoussis. 1995. Evidence of a locus for orofacial clefting on human chromosome $6 \mathrm{p} 24$ and STS content map of the region. Hum. Mol. Genet. 4: 121-128.

Eiberg, H., D. Bixler, L.S. Nielsen, P.M. Conneally, and J. Mohr. 1987. Suggestion of linkage of a major locus for nonsyndromic orofacial cleft with F13A and tentative assignment to chromosome 6. Clin. Genet. 32: 129-132.

Francke, U. 1994. Digitized and differentially shaded human chromosome ideograms for genomic applications. Cytogenet. Cell Genet. 65: 206-218.

Gaynor, R.B., C. Muchardt, A. Diep, T.K. Mohandas, R.S. Sparkes, and A.J. Lusis. 1991a. Localization of the zinc finger DNA-binding protein HIV-EP1/MBP-1/PRDII-BF1 to human chromosome $6 \mathrm{p} 22.3-\mathrm{p} 24$. Genomics 9: 758-761.

Gaynor, R.B., C. Muchardt, Y.R. Xia, I. Klisak, T. Mohandas, R.S. Sparkes, and A.J. Lusis. 1991b.
Localization of the gene for the DNA-binding protein AP-2 to human chromosome 6p22.3-pter. Genomics 10: $1100-1102$

Green, E.D. and M.V. Olson. 1990. Systematic screening of yeast artificial-chromosome libraries by use of the polymerase chain reaction. Proc. Nat. Acad. Sci. 87: 1213-1217.

Gyapay, G., J. Morissette, A. Vignal, C. Dib, C. Fizames, P. Millasseau, S. Marc, G. Bernardi, M. Lathrop, and J. Weissenbach. 1994. The 1993-94 Genethon human genetic linkage map. Nat. Genet. 7: 246-339.

Hecht, J.T., Y. Wang, B. Connor, S.H. Blanton, and S.P. Daiger. 1993. Nonsyndromic cleft lip and palate: No evidence of linkage to HLA or factor 13A. Am. J. Hum. Genet. 52: $1230-1233$.

Holmquist, G.P. 1992. Chromosome bands, their chromatin flavors, and their functional features. Am. J. Hum. Genet. 51: 17-37.

Jodice, C., M. Frontali, F. Persichetti, A. Novelletto, M. Pandolfo, M. Spadaro, P. Giunti, G. Schinaia, P. Lulli, P. Malaspina, R. Plasmati, R. Tola, A. Antonelli, S. Di Donato, C. Morcutti, J. Weissenbach, H.M. Cann, and L. Terrenato. 1993. The gene for spinal cerebellar ataxia 1 (SCA1) is flanked by two closely linked highly polymorphic microsatellite loci. Hum. Mol. Genet. 2: $1383-1387$.

Kendall, E., C.A. Sargent, and R.D. Campbell. 1990. Human major histocompatibility complex contains a new cluster of genes between the HLA-D and complement C4 loci. Nucleic Acids Res. 18: 7251-7257.

Kondoh, T., H. Kanno, L. Chang, and A. Yoshida. 1991. Genomic structure and expression of human guanosine monophosphate reductase. Hum. Genet. 88: 219-224.

Kouprina, N., M. Eldarov, R. Moyzis, M. Resnick, and V. Larionov. 1994. A model system to assess the integrity of mammalian YACs during transformation and propagation in yeast. Genomics 21: 7-17.

Kwiatkowski, T.J. Jr., H.T. Orr, S. Banfi, A.E. McCall, C. Jodice, F. Persichetti, A. Novelletto, F. LeBorgne-DeMarquoy, L.A. Duvick, M. Frontali, S.H. Subramony, A.L. Beaudet, L. Terrenato, H.Y. Zoghbi, and L. P. W. Ranum. 1993. The gene for autosomal dominant spinocerebellar ataxia (SCA1) maps centromeric to D6S89 and shows no recombination, in nine large kindreds, with a dinucleotide repeat at the AM10 locus. Am. J. Hum. Genet. 53: 391-400.

Larin, Z., A.P. Monaco, and H. Lehrach. 1991. Yeast artificial chromosome libraries containing large inserts from mouse and human DNA. Proc. Nat. Acad. Sci. 88: $4123-4127$.

Le Borgne-Demarquoy, F., T.J. Kwiatowski Jr., and H.Y. Zoghbi. 1991. Two dinucleotide repeat polymorphisms at the D6S202 locus. Nucleic Acids Res. 19: 6060. 


\section{MAP OF HUMAN CHROMOSOME 6P23}

Litt, M. and J.A. Luty. 1990. Dinucleotide repeat polymorphism at the D6S89 locus. Nucleic Acids Res. 18: 4301.

Murano, I., M. Tsukahara, T. Kajii, and A. Yoshida. 1994 Mapping of the human guanosine monophosphate reductase gene (GMPR) to chromosome $6 \mathrm{p} 23$ by fluorescence in situ hybridization. Genomics 19: $179-180$.

Nemani, M., D. Cherif, H. Chesne, M. Pelandakis, P. Ougen, R. Berger, J. Weissén̄bach, D. Le Paslier, D. Cohen, and H.M. Cann. 1994. A YAC contig in 6p23 based on sequence tagged sites. Genomics 22: 388-396.

Nizetic, D., G. Zehetner, A.P. Monaco, L. Gellen, B.D. Young, and H. Lehrach. 1991. Construction, arraying, and high-density screening of large insert libraries of human chromosomes $\mathrm{X}$ and 21: Their potential use as reference libraries. Proc. Nat. Acad. Sci. 88: 3233-3237.

Nizetic, D., L. Gellen, R.M. Hamvas, R. Mott, A. Grigoriev, R. Vatcheva, G. Zehetner, M.L. Yaspo, A. Dutriaux, C. Lopes, J.-M. Delabar, C. Van Broekhoven, M.-C. Potier, and H. Lehrach. 1994a. An integrated YAC-overlap and "cosmid-pocket" map of the human chromosome 21. Hum. Mol. Genet. 3: 759-770.

Nizetic, D., S. Monard, B. Young, F. Cotter, G. Zehetner, and H. Lehrach. 1994b. Construction of cosmid libraries from flow-sorted human chromosomes $1,6,7,11,13$, and 18 for reference library resources. Mamm. Genome 5: $801-802$.

Orphanos, V., M. Santibanez-Koref, G. McGown, Y. Hey, C. Rackstraw, and J.M. Boyle. 1994. Physical mapping of 43 STSs to human chromosome 6. Genomics 20: 301-304.

Orr, H.T., M.Y. Chung, S. Banfi, T.J. Kwiatkowski Jr., A. Servadio, A.L. Beaudet, A.E. McCall, L.A. Duvick, L.P. Ranum, and H.Y. Zoghbi. 1993. Expansion of an unstable trinucleotide CAG repeat in spinocerebellar ataxia type 1 . Nature Genet. 4: 221-226.

Pappas, G.J., M.H. Polymeropoulos, J.M. Boyle, and J.M. Trent. 1995. Regional assignment by hybrid mapping of 36 expressed sequence tags (ESTs) on human chromosome 6. Genomics 25: 124-129.

Polymeropoulos, M.H., H. Xiao, A. Glodek, M. Gorski, M.D. Adams, R.F. Moreno, M.G. Fitzgerald, J.C. Venter, and C.R. Merril. 1992. Chromosomal assignment of 46 brain cDNAs Genomics 12: 492-496.

Ranum, L.P., M.Y. Chung, L.A. Duvick, H.Y. Zoghbi, and H.T. Orr. 1991. Dinucleotide repeat polymorphism at the D6S109 locus. Nucleic Acids Res. 19: 1171.

Riley, J., R. Butler, D. Ogilvie, R. Finniear, D. Jenner, S. Powell, R. Anand, J.C. Smith, and A.F. Markham. 1990. A novel, rapid method for the isolation of terminal sequences from yeast artificial chromosome (YAC) clones. Nucleic Acids Res. 18: 2887-2890.
Rooney, D.E. and B.H. Czepulkowski. 1992. Prenatal diagnosis and tissue culture. In Human cytogenetics. A practical approach, 2nd ed. (ed. D.E. Rooney and B.H. Czepulkowski), pp. 55-89. IRL Press, Oxford, UK.

Sargent, C.A., I. Dunham, and R.D. Campbell. 1989. Identification of multiple HTF-island associated genes in the human major histocompatibility complex class III region. EMBO I. 8: 2305-2312.

Sealey, P.G., P.A. Whittaker, and E.M. Southern. 1985. Removal of repeated sequences from hybridisation probes. Nucleic Acids Res. 13: 1905-1922.

Senger, G., J. Ragoussis, J. Trowsdale, and D. Sheer. 1993. Fine mapping of the human MHC class II region within chromosome band $6 \mathrm{p} 21$ and evaluation of probe ordering using interphase fluorescence in situ hybridization. Cytogenet. \& Cell Genet. 64: 49-53.

Southern, E.M., R. Anand, W.R. Brown, and D. S Fletcher. 1987. A model for the separation of large DNA molecules by crossed field gel electrophoresis. Nucleic Acids Res. 15: 5925-5943.

Spring, B., C. Fonatsch, C. Muller, G. Pawelec, J. Kompf, P. Wernet, and A. Ziegler. 1985. Refinement of HLA gene mapping with induced B-cell line mutants. Immunogenetics 21: 277-291.

Sutherland, G.R., P.B. Jacky, E. Baker, and A. Manuel 1983. Heritable fragile sites on human chromosomes. X. New folate-sensitive fragile sites: $6 \mathrm{p} 23,9 \mathrm{p} 21,9 \mathrm{q} 32$, and 11q23. Am. J. Hum. Genet. 35: 432-437.

Terrenato, L., C. Jodice, P. Blasi, A. Loizedda, L. Contu, J. Buard, G. Vergnaud, P. Humphries, R. Kumar-Singh, C. Massart, and H.M. Cann. 1994. The EUROGEM map of human chromosome 6. Eur. J. Hum. Genet. 2: 214-215.

Van Cong, N., S. Fichelson, M.S. Gross, B. Sola, D. Bordereaux, M.F. de Tand, S. Guilhot, S. Gisselbrecht, J. Frezal, and P. Tambourin. 1989. The human homologues of Fim1, Fim2/c-Fms, and Fim3, three retroviral integration regions involved in mouse myeloblastic leukemias, are respectively located on chromosomes 6p23, 5q33, and 3q27. Hum. Genet. 81: 257-263.

Vintiner, G.M., K.K. Lo, S.E. Holder, R.M. Winter, and S. Malcolm. 1993. Exclusion of candidate genes from a role in cleft lip with or without cleft palate: Linkage and association studies. J. Med. Genet. 30: 773-778.

Volz, A., C. Fonatsch, and A. Ziegler. 1992. Regional mapping of the gene for autosomal dominant spinocerebellar ataxia (SCA1) by localizing the closely linked D6S89 locus to 6p24.2-p23.05. Cytogenet. Cell Genet. 60: 37-39.

Volz, A., J.M. Boyle, H.M. Cann, R.W. Cottingham, H.T. Orr, and A. Ziegler. 1994. Report of the Second International Workshop on human chromosome 6. Genomics 21: 464-472. 


\section{OLAVESEN ET AL.}

von Lindern, M., M. Fornerod, S. van Baal, M. Jaegle,T. de Wit, A. Buijs, and G. Grosveld. 1992. The translocation $(6 ; 9)$, associated with a specific subtype of acute myeloid leukemia, results in the fusion of two genes, dek and can, and the expression of a chimeric, leukemia-specific dek-can mRNA. Mol. Cell. Biol.

12: $1687-1697$

Wang, S., C. Sun, C.A. Walczak, J.S. Ziegle, B.R. Kipps, L.R. Goldin, and S.R. Diehl. 1995. Evidence for a susceptibility locus for schizophrenia on chromosome 6pter-p22. Nature Genet. 10: 41-46.

Weissenbach, J., G. Gyapay, C. Dib, A. Vignal, J. Morissette, P. Millasseau, G. Vaysseix, and M. Lathrop. 1992. A second-generation linkage map of the human genome. Nature 359: 794-801.

Zehetner, G. and H. Lehrach. 1994. The Reference Library System-Sharing biological material and experimental data. Nature 367: 489-491.

Received August 7, 1995; accepted in revised form October 16, 1995. 


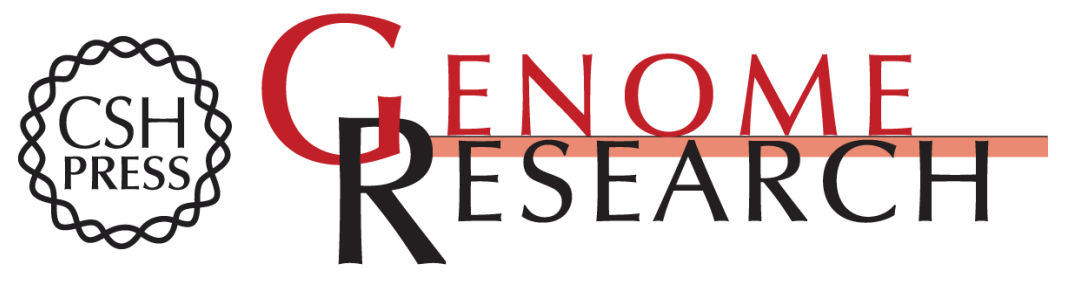

\section{An integrated map of human chromosome 6p23.}

M G Olavesen, A F Davies, S J Broxholme, et al.

Genome Res. 1995 5: 342-358

Access the most recent version at doi:10.1101/gr.5.4.342

$\begin{array}{ll}\text { References } & \begin{array}{l}\text { This article cites } 57 \text { articles, } 5 \text { of which can be accessed free at: } \\ \text { http://genome.cshlp.org/content/5/4/342.full.html\#ref-list-1 }\end{array}\end{array}$

License

Email Alerting Receive free email alerts when new articles cite this article - sign up in the box at the Service top right corner of the article or click here.

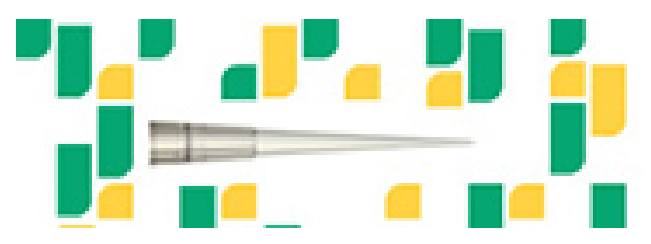

To subscribe to Genome Research go to:

https://genome.cshlp.org/subscriptions 